\title{
Approaching TEL in university teaching: the faculty training need
}

\author{
Guglielmo Trentin ${ }^{1}$, Jane Klobas ${ }^{2,3}$ and Stefano Renzi ${ }^{2}$ \\ 1 Institute for Educational Technology, National Research Council, \\ Genoa, Italy (trentin@itd.cnr.it - http://www.itd.cnr.it) \\ 2 University of Western Australia, Perth, Australia \\ (jane.klobas@uwa.edu.au - http://www.uwa.edu.au) \\ 3 Bocconi University, Milan, Italy \\ (stefano.renzi@unibocconi.it - http://www.unibocconi.it)
}

\begin{abstract}
The introduction of ICT in university teaching is a long process and is strongly conditioned by many variables, first of all the level of knowledge the faculty members possess about the educational uses of ICT and the related instructional design approaches. This is the key issue on the basis of which the two specific training projects referred in this paper have been launched. After describing the related training approaches, some considerations will be made on the different role and status of those teachers who no longer restrict themselves to classroom teaching but who intend to complement or replace it with online education activities.
\end{abstract}

\section{Introduction}

Faculty members play a significant role in introducing the educational use of ICT in university teaching and should be capable of assessing the value that Technology Enhanced learning (TEL) [1] adds to their teaching [2, 3, 4]. They therefore need to acquire a fresh culture that envisages these approaches not so much as an antagonism or alternative to face to face teaching but as a further possibility. For example, there are cases where time and space impose severe constraints on attending classroom lessons or situations where TEL methodologies prove to be more effective didactically by being able to play separately on the element of "space" (doing as much as possible at home, locally, perhaps assisted at a distance or involved in group learning) and "time" (when conditions enable it).

Teachers generally face an awkward moment during their initial experiences of using TEL when it would be useful to provide them with support in their choice of methods in accordance with the teaching objectives. Bearing this in mind several 
Italian universities have promoted training projects aimed at culturally developing faculty members in use of ICT in teaching and learning. The two cases presented here highlight two different approaches.

\section{The ODL experience at the University of Turin}

The ODL Project [5] at the University of Turin (started in 1999) consisted of a series of initiatives to channel methodological/technological abilities towards teachers already active in the educational use of ICT and towards training those who, despite being aware of the new opportunities offered by TEL, had not yet been given the chance to come to grips with using them. For teachers accustomed to TEL, this meant taking action to consolidate and systemize existing approaches; for the others, ad hoc project-oriented training courses focused on creating a personal TEL project.

The training model is broken down into two levels: basic training and advanced training.

Basic training is aimed at all teachers involved in the training programme and is provided during the first year. The main purpose is for teachers to acquire the minimum skills for designing and developing their first ICT application to support their own teaching. During basic training, topics related to networked learning are tackled fairly lightly, and the teachers' first approach to TEL almost always starts out by creating websites with learning materials.

Advanced training is therefore meant for teachers who, after their first experience of educational ICT uses (as a result of basic training or previous personal experience) intend to acquire TEL methods more deeply, both in the design of educational econtent (and more specifically learning-objects) and the management of networked collaborative learning.

In other words, while basic training envisages a sort of annual "call for participation" for the recruitment of those who want an introduction to TEL, advanced training, on the other hand, is based on explicit request from faculty members interested in acquiring greater skills to teach with ICT.

\section{The BEL experience at the University "Bocconi" of Milan}

The Turin experience could be described as bottom-up, in the sense that the diffusion of knowledge about TEL, beginning with the teacher, leaves the teacher to choose "if", "how" and "when" to use TEL in their own teaching. This approach works well if the objective is cultural. On the other hand, systemic approaches can be adopted by universities that provide strong organizational commitment to adoption of TEL. The BEL (Bocconi E-Learning) project illustrates one such approach.

Bocconi University, a prestigious business university in Milan, had significant success in introducing TEL, but eight years later wanted to move further forward.

In 1998, Bocconi began its TEL journey with the "B-learning" project. As part of this project, the university bought a learning management system (LMS) and established the technical infrastructure to support university-wide use of TEL. Five 
pilot teachers participated with three courses re-designed with the assistance of LMS experts. Subsequently, other teachers spontaneously adopted the platform and within three years $25 \%$ of the courses used TEL [6]. By the 2004-2005 academic year, almost all of Bocconi's courses incorporated some form of TEL, but most TEL usage was limited to upload of teaching material. Few courses involved students in online activities or computer-supported collaborative learning.

In the meantime, the increased number of Bocconi students spending a semester off-campus as interns or on exchange led the University to reconsider it use of TEL. A new project was initiated with the goal of enabling Bocconi students who were temporarily off-campus to participate in courses they would otherwise have taken on-campus. Six optional courses, involving nine teachers, were selected for participation in the first year. They were granted funds to buy technology, expertise and teaching relief.

Although the University's brief to the teachers was quite open, a number of requirements were set. They included: (1) the participation of the teachers in formal course design activities; (2) the online version of the course had to be offered in the same semester and by the same teacher as the classroom version of the course; (3) student participation in online activities should be compulsory.

The teachers selected for the new initiative included one of the original BEL project pilot teachers. He provided initial leadership, recommended they work together as a project team, and encouraged them to incorporate activities based on online collaborative learning where it was appropriate. The group agreed and decided to invite an experienced instructional designer to work with them.

The instructional designer held two introductory half day seminars, then worked individually with the teachers on design of the online versions of their courses. All teachers agreed to work to the same schedule for course design during the semester that preceded initiation of the online course:

- macro-design: definition of course objectives and goals, evaluation criteria, the types of activities to be incorporated, and preparation of an initial course outline;

- micro-design: detailed design of course modules, activities and timeline, reflected in a more detailed course outline;

- development of learning materials;

- "audit" of the revised courses by the instructional designer and participants.

Throughout these stages, teachers experimented with a range of technologies and activities. The first two re-designed courses were introduced to postgraduate students in September 2007. At the time of writing, they are being formally evaluated.

\section{Some concluding remarks}

Research carried out on the Turin and Bocconi University projects highlights two key conditions for fostering the process of introducing TEL in university teaching: cultural development of faculty members in the use of TEL approaches; and renegotiation of the teachers' new role as 'e-teacher'. In the first case, it is necessary: - to adopt ad hoc training courses for faculty aimed at establishing initial contact with TEL and at steadily introducing the learning/teaching processes; 
- to support faculty members in their first experience as an instructional designer of an online course.

In the second case, careful reflection is needed to understand how the teachers' role will change due to adopting innovative teaching methods with and through the use of ICT. In fact, although teachers continue to play a central role in TEL, their function inevitably tends to change with respect to classroom teaching: from a classroom teacher to a facilitator of the learning process where they are content experts. They contribute towards preparing e-materials and supervise online interactive activities. How much one changes clearly depends on the type of learning process to be fostered and whether it is partly or entirely based on the use of ICT. However, this often entails a work-overload, above all when teachers, besides TEL solutions, are anyway required to hold classroom lessons.

The importance of the role of e-teacher can be observed particularly when approaches based on networked collaborative learning are adopted.

To sum up, we may conclude that the study of and experimentation with TEL models is quite well developed, even if there is still significant room for improvement in their application. On the other hand, the training of faculty members, the norms (including those related to intellectual property of e-content), the organization, logistics and infrastructure still constitute serious obstacles for a solid university-wide implementation of the relative practices. Nevertheless it is comforting to observe that an increasing number of teachers are currently involved in experimenting with the use of TEL as a support for their teaching.

\section{References}

1. TEL Committee, University of Texas (2004). Report of Technology Enhanced Learning Committee. Available: http://www.utexas.edu/provost/planning/reports/ TEL_Report_2004.pdf.

2. Clulow, V., \& Brace-Govan, J. (2003). Web-based learning: Experience-based research. In A. K. Aggarwal (Ed.), Web-Based Education: Learning from Experience (pp.49-70). Hershey, PA: Information Science Publishing.

3. Hazemi R., \& Hailes S. (2002). Introduction. In R. Hazemi and S. Hailes (Eds.), The Digital University: Building a Learning Community. London: Springer.

4. Zemsky, R., \& Massy, W.F. (2004). Thwarted innovation: what happened to elearning and why. Final Report for The Weatherstation Project of the Learning Alliance at University of Pennsylvania. Available: http://www.csudh.edu/ dearhabermas/WeatherStation_Report.pdf.

5. Trentin, G. (2008). TEL and university teaching: different approaches for different purposes, International Journal on E-Learning, 7(1), 117-132.

6. Klobas, J.E., \& Renzi, S. (2003). Integrating online educational activities in traditional courses: University-wide lessons after three years. In A. K. Aggarwal (Ed.), Web-Based Education: Learning from Experience (pp. 415-439). Hershey, PA: Information Science Publishing. 